Journal of Agriculture and Natural Resources (2018) 1(1): 51-61

ISSN: 2661-6270 (Print), ISSN: 2661-6289 (Online)

\title{
Research Article \\ Verification of disease management technology on lentil against Stemphylium blight at farmer's field in Nepal
}

\author{
Subash Subedi ${ }^{1}{ }^{*}$ and Sarswati Neupane ${ }^{1}$ \\ ${ }^{1}$ Nepal Agricultural Research Council, National Maize Research Program \\ Rampur, Chitwan, Nepal \\ * Correspondence: subedi.subash1@ gmail.com \\ ORCID: https://orcid.org/0000-0003-3739-1773
}

Received: July 18; Accepted: October 27; Published: December 09.

(C) Copyright: Subedi and Neupane (2018).

(c) (1) (9) This work is licensed under a Creative Commons Attribution-NonCommercial 4.0
International License.

\begin{abstract}
Technologies generated from lentil (Lens culinaris Medik) stemphylium blight (Stemphylium botryosum Walr) management experiments were verified at farmers field of 5 districts viz., Chitawan, Rautahat, Dang, Parsa and Banke during two winter seasons of 2013-2014 and 20142015. The experiment was laid out in randomized complete block design with factorial arrangement of treatments and replicated 4 times. The plot size was $340 \mathrm{~m}^{2}$ (1 Kattha) with 25 $\mathrm{cm}$ row to row spacing. There were altogether 3 factors of the experiment i.e. year (2013-2014 and 2014-2015), location (5 districts) and package of practice (improved and farmers practice). The higher crop yield (1142.50 kg/ha) with lower disease index $(34.95 \%)$ and higher benefit cost ratio of 2.42 were recorded in the farmers field of Banke district following seed rate $(30 \mathrm{~kg} / \mathrm{ha}), 8$ hour primed improved variety (Black lentil), fertilizer doze of $(20: 40: 20 \mathrm{NPK} \mathrm{kg} / \mathrm{ha}+1 \mathrm{~kg} / \mathrm{ha} \mathrm{B}$ basal doze) and subsequent 3 sprays of Dithane M-45 @ $2.5 \mathrm{~g} / \mathrm{l}$ of water at 10 days interval.
\end{abstract}

Keywords: Lentil, management, stemphylium blight, technology, verification

Correct citation: Subedi, S., \& Neupane, S. (2018). Verification of disease management technology on lentil against Stemphylium blight at farmer's field in Nepal. Journal of Agriculture and Natural Resources, 1(1), 51-61. 
Journal of Agriculture and Natural Resources (2018) 1(1): 51-61

ISSN: 2661-6270 (Print), ISSN: 2661-6289 (Online)

\section{INTRODUCTION}

Stemphylium blight caused by Stemphylium botryosum Walr is a serious threat to lentil cultivation in Nepal. This disease caused leaf blight that can result in large scale defoliation of plants. The disease was first reported in 1993 in Nepal and widespread throughout major growing areas (Bayaa et al., 1998) and later observed increasingly in Banke, Bardia, Rupandehi, Chitwan, Nepalgunj, Makwanpur, Bara, Parsa and Rautahat districts (Joshi, 2006) and in some crop growing districts estimated yield losses of $60-90 \%$ have been assessed (GLRP, 2012). Banniza et al. (2004) reported 62\% yield loss due to stemphylium blight in Bangladesh. Various technologies regarding the improved varieties and different crop management practices of lentil have so far been developed and released in Nepal. However studies regarding the adoption of technologies were very limited. The role of extension services for the technology demonstration and dissemination are so vital for the adoption of so called verified technologies in farmer's field. The on-station research works focusing on integrated disease management of lentil stemphylium blight were carried out at Grain legumes Research Programme, Rampur, Chitwan during 2011-2014. The technology that was developed on-station including appropriate agronomic practices with disease resistant variety and timely application of fungicides should be verified at farmer's field first and then recommended and delivered through extension services.

In view of the above facts, the present research work was undertaken with the objective of evaluation of the best disease management technology against lentil stemphylium blight in farmers field.

\section{MATERIALS AND METHODS}

Technologies generated from lentil stemphylium blight management experiments were verified at farmers field of 5 districts viz., Rampur (Chitawan), Dumariya (Rautahat), Lalmatiya (Dang), Bagwana (Parsa) and Baijapur (Banke) during two winter seasons of 2013-2014 and 2014-2015. The experiment was laid out in randomized complete block design with factorial arrangement of treatments and replicated 4 times. The plot size was $340 \mathrm{~m}^{2}$ (=1 Kattha) with $25 \mathrm{~cm}$ row to row spacing. There were altogether 3 factors of the experiment i.e. year (2013-2014 and 2014-2015), location (5 districts) and package of practice (improved and farmers practice). Improved practice includes improved variety (Black lentil- (Source-Nuwakot, Pedigree- Black lentil, OriginNepal $))+$ seed priming + Recommended seed rate $(30 \mathrm{~kg} / \mathrm{ha})+$ fertilizer doze (20:40:20 NPK $\mathrm{kg} / \mathrm{ha}+1 \mathrm{~kg} / \mathrm{ha}$ B basal doze) + mancozeb $2.5 \mathrm{~g} / \mathrm{l}$ of water (3 sprays at 10 days interval during vegetative stage) with till while farmers practice includes high seed rate $(60 \mathrm{~kg} / \mathrm{ha})$ in relay condition only. The observations were recorded on Percent Disease Index (PDI) and yield $(\mathrm{kg} / \mathrm{ha})$. Disease severity data was recorded using 1-9 scoring scale from 25 randomly tagged plants/plot (Morrall and Mckenzie, 1974).Similarly Percent Disease Index (PDI) was computed on the basis of recorded data according to the formula (Wheeler, 1969). The benefit cost analysis was also carried out to assess the profitability of the generated technology in farmers field. 
Journal of Agriculture and Natural Resources (2018) 1(1): 51-61

ISSN: 2661-6270 (Print), ISSN: 2661-6289 (Online)

All data were analyzed statistically using Microsoft Excel and MSTAT-C computer package program. Treatment mean was compared using Duncan's Multiple Range Test (DMRT) at 1 and $5 \%$ levels of significance.

\section{RESULTS}

Year

The grain yield was highly significant $(\mathrm{P} \leq 0.05)$ with the lentil season of different years in technology verification experiment conducted at 5 districts of Nepal. During second year of experimentation (2014-2015), the higher grain yield $(735.15 \mathrm{~kg} / \mathrm{ha}$ ) was found with the lower percent disease index $(53.47 \%)$ however disease index was not significantly different among the years of cultivation (Table 1).

Table 1. Stemphylium blight disease severity and yield of lentil in on-farm participatory technology verification experiment as affected by cropping season.

\begin{tabular}{lll}
\hline \multicolumn{1}{c}{ Lentil cropping seasons } & Stemphylium blight (PDI) & Yield (kg/ha) \\
\hline $2013 / 14$ (Y1) & $54.55^{\dagger}$ & 689.97 \\
$2014 / 15($ Y2) & 53.47 & 735.15 \\
\hline F Test & NS & $* *$ \\
CV\% & 5.78 & 10.78 \\
\hline
\end{tabular}

${ }^{\dagger}$ Means of 4 replication. PDI-percent disease index, kg/ha- Kilogram per hectare. NS- not significant, ** - highly significant

\section{Location}

The stemphylium blight disease index and crop yield both were significant $(\mathrm{P} \leq 0.05)$ among 5 different locations in technology verification experiment during 2013-2015. The higher crop yield $(744.37 \mathrm{~kg} / \mathrm{ha})$ with lower disease index $(51.94 \%)$ was recorded in farmers field of Rautahat district followed by $52.14 \%$ percent disease index with $739.19 \mathrm{~kg} / \mathrm{hacrop}$ yield at Parsa district. The lower crop yield $(677.87 \mathrm{~kg} / \mathrm{ha})$ with higher disease index $(56.84 \%)$ was recorded in Chitwan district (Table 2).

Table 2. Stemphylium blight disease severity and yield of lentil in on-farm participatory technology verification experiment as affected by locations during 2013-2015.

\begin{tabular}{lll}
\hline Location & Stemphylium blight (PDI) & Yield (kg/ha) \\
\hline Chitwan (L1) & $56.84^{\dagger}$ & 677.87 \\
Rautahat (L2) & 51.94 & 744.37 \\
Dang (L3) & 53.39 & 716.69 \\
Parsa (L4) & 52.14 & 739.19 \\
Banke (L5) & 55.76 & 684.69 \\
\hline F Test & $* *$ & $*$ \\
CV\% & 5.78 & 10.78 \\
\hline
\end{tabular}

${ }^{\dagger}$ Means of 4 replication. PDI-percent disease index, Kg/ha- Kilogram per hectare. *- significant, **- highly significant 
Journal of Agriculture and Natural Resources (2018) 1(1): 51-61

ISSN: 2661-6270 (Print), ISSN: 2661-6289 (Online)

\section{Interaction effect between year and location}

The stemphylium blight disease index and lentil yield both were highly significant $(\mathrm{P} \leq 0.05)$ with the interaction effect between year and locations in technology verification experiment in the farmers field of 5 districts of Nepal. The higher crop yield $(811.50 \mathrm{~kg} / \mathrm{ha})$ with lower percent disease index (50.68\%) was recorded in the farmers field of Rautahat district in the second year of experiment (2014-2015) followed by the farmers field of Parsa district in first year (20132014) of experiment i.e. $51.00 \%$ disease index with $780.75 \mathrm{~kg} / \mathrm{ha}$ lentil yield. The lower crop yield $(605.62 \mathrm{~kg} / \mathrm{ha}$ ) with higher disease index $(58.99 \%)$ was recorded in the farmers field of Banke district during first year of experimentation (Table 3).

Table 3. Interaction effect between cropping season year and location on disease severity and lentil yield in on-farm technology verification experiment during 2013-2015.

\begin{tabular}{lll}
\hline Year $\times$ Location & Stemphylium blight (PDI) & Yield (kg/ha) \\
\hline Y1L1 & $55.26^{\dagger}$ & 684.37 \\
Y1L2 & 56.82 & 677.25 \\
Y1L3 & 53.19 & 701.87 \\
Y1L4 & 51.00 & 780.75 \\
Y1L5 & 58.99 & 605.62 \\
Y2L1 & 56.86 & 671.37 \\
Y2L2 & 50.68 & 811.50 \\
Y2L3 & 52.54 & 731.50 \\
Y2L4 & 53.27 & 697.62 \\
Y2L5 & 51.52 & 763.75 \\
\hline F Test & $* *$ & $* *$ \\
CV\% & 5.78 & 10.78 \\
\hline${ }^{\dagger}$ Means of 4 replication. PDI-percent disease index, kg/ha- Kilogram per hectare. Y1- 2013/14, Y2- 2014/15, L1- Chitwan, L2- \\
Rautahat, L3-Dang, L4- Parsa, L5- Banke. **- highly significant
\end{tabular}

\section{Cultivation Practice}

The cultivation practices had highly significant $(\mathrm{P} \leq 0.05)$ effect in reducing the disease (PDI) and increase in yield in farmer's field of Chitwan, Rautahat, Dang, Parsa, and Banke districts during 2013-2015. The lower disease index (39.14\%) with higher yield (1032.30 kg/ha) was recorded in recommended improved practice while farmers field practiced with their own technology had higher disease index (68.89\%) with lower crop yield (392.82 kg/ha) (Table 4).

\section{Interaction effect between cropping season year and practice}

The stemphylium blight disease index was significant $(\mathrm{P} \leq 0.05)$ with the interaction effect between lentil cropping season year and practice in technology verification experiment in the farmers field of 5 districts of Nepal. The lower percent disease index (37.77\%) with the higher crop yield $(1060.00 \mathrm{~kg} / \mathrm{ha})$ was recorded in farmers field following recommended practice during second year of experimentation although crop yield was not significantly different with the interaction effect between cropping seasons and cultivation practice. The higher disease index $(69.18 \%)$ with lower crop yield $(375.35 \mathrm{~kg} / \mathrm{ha})$ was found in the farmers field following their 
Journal of Agriculture and Natural Resources (2018) 1(1): 51-61

ISSN: 2661-6270 (Print), ISSN: 2661-6289 (Online)

own practice of cultivation during first year of experimentation (Table 5).

Table 4. Stemphylium blight disease and yield of lentil in on-farm technology verification experiment as affected by cultivation practice during 2013-2015.

\begin{tabular}{lll}
\hline Practice & Stemphylium blight (PDI) & Yield (kg/ha) \\
\hline Recommended practice (P1) & $39.14^{\dagger}$ & 1032.30 \\
Farmer practice (P2) & 68.89 & 392.82 \\
\hline F Test & $* *$ & $* *$ \\
CV\% & 5.78 & 10.78 \\
\hline
\end{tabular}

\footnotetext{
${ }^{\dagger}$ Means of 4 replication. PDI-percent disease index, kg/ha- Kilogram per hectare. Improved practice (P1) includes improved variety (Black lentil) + seed priming + Recommended seed rate $(30 \mathrm{~kg} / \mathrm{ha})+$ fertilizer doze (20:40:20 NPK kg/ha+ $1 \mathrm{~kg} / \mathrm{ha} \mathrm{B}$ basal doze) + mancozeb $2.5 \mathrm{~g} / \mathrm{l}$ of water (3 sprays at 10 days interval during vegetative stage) with till while farmer practice (P2) includes only high seed rate $(60 \mathrm{~kg} / \mathrm{ha})$ in relay condition. **- highly significant
}

Table 5. Interaction effect between cropping season year and practice on disease index and lentil yield in on-farm technology verification experiment during 2013-2015

\begin{tabular}{lll}
\hline Year $\times$ Practice & Stemphylium blight $(\mathrm{PDI})$ & Yield $(\mathrm{kg} / \mathrm{ha})$ \\
\hline Y1P1 & $40.50^{\dagger}$ & 1004.60 \\
Y1P2 & 69.18 & 375.35 \\
Y2P1 & 37.77 & 1060.00 \\
Y2P2 & 68.60 & 410.30 \\
\hline F Test & $*$ & $\mathrm{NS}$ \\
$\mathrm{CV} \%$ & 5.78 & 10.78 \\
\hline${ }^{\dagger}$ Means of 4 replication. PDI-percent disease index, kg/ha-Kilogram per hectare. Y1- 2013/14, Y2- 2014/15, Improved \\
practice (P1) includes improved variety (Black lentil) + seed priming + Recommended seed rate $(30 \mathrm{~kg} / \mathrm{ha})+$ \\
fertilizer doze (20:40:20 NPK kg/ha+ 1 kg/haB basal doze) + mancozeb 2.5 g/l of water (3 sprays at 10 days \\
interval during vegetative stage) with till while farmer practice (P2) includes only high seed rate (60kg/ha) in \\
relay condition. *- significant, NS- not significant
\end{tabular}

\section{Interaction effect between location and practice}

The crop yield and disease index both were significant $(\mathrm{P} \leq 0.05)$ with the interaction effect between location and cultivation practice in on-farm technology verification experiment during 2013-2015. The higher crop yield $(1066.87 \mathrm{~kg} / \mathrm{ha})$ with lower disease index $(35.79 \%)$ was recorded in the farmers field of Rautahat district who followed recommended practice followed by Dang district with recommended practice i.e. 36.96\% disease index and lentil yield (1061.86 $\mathrm{kg} / \mathrm{ha})$. The lower crop yield $(322.50 \mathrm{~kg} / \mathrm{ha})$ with higher disease index $(71.85 \%)$ was recorded in the farmers field of Banke district following their own cultivation practice (Table 6). 
Journal of Agriculture and Natural Resources (2018) 1(1): 51-61

ISSN: 2661-6270 (Print), ISSN: 2661-6289 (Online)

Table 6. Interaction effect between location and practice on disease severity and lentil yield in on-farm technology verification experiment during 2013-2015.

\begin{tabular}{lll}
\hline Location $\times$ Practice & Stemphylium blight (PDI) & Yield (kg/ha) \\
\hline L1P1 & $43.25^{\dagger}$ & 937.50 \\
L1P2 & 68.49 & 418.25 \\
L2P1 & 35.79 & 1066.87 \\
L2P2 & 66.91 & 421.85 \\
L3P1 & 36.96 & 1061.86 \\
L3P2 & 70.44 & 371.50 \\
L4P1 & 39.67 & 1048.37 \\
L4P2 & 66.77 & 430.00 \\
L5P1 & 40.01 & 1046.84 \\
L5P2 & 71.85 & 322.50 \\
\hline F Test & $*$ & $* *$ \\
CV\% & 5.78 & 10.78 \\
\hline
\end{tabular}

\footnotetext{
${ }^{\dagger}$ Means of 4 replication. PDI-percent disease index, Kg/ha- Kilogram per hectare. L1- Chitwan, L2- Rautahat, L3-Dang, L4Parsa, L5- Banke. Improved practice (P1) includes improved variety (Black lentil) + seed priming + Recommended seed rate $(30 \mathrm{~kg} / \mathrm{ha})+$ fertilizer doze $(20: 40: 20 \mathrm{NPK} \mathrm{Kg} / \mathrm{ha}+1 \mathrm{~kg} / \mathrm{haB}$ basal doze $)+$ mancozeb $2.5 \mathrm{~g} / \mathrm{l}$ of water (3 sprays at 10 days interval during vegetative stage) with till while farmer practice (P2) includes only high seed rate $(60 \mathrm{~kg} / \mathrm{ha})$ in relay condition. $*$ - significant, $* *$ - highly significant
}

\section{Interaction effect among cropping year, location and cultivation practice}

The higher crop yield (1142.50 kg/ha) with lower disease index (34.95\%) was recorded in the farmers field of Banke district following recommended practice during second year of experimentation although both variables were not significant with the interaction effect among year, location and cultivation practice in technology verification experiment.

The higher disease index (73.57\%) with lower crop yield $(260.00 \mathrm{~kg} / \mathrm{ha})$ was observed in farmers field of Banke district who followed their own practice of cultivation (P1) during first year of experimentation. (Table7).

\section{Relationship between disease index and crop yield}

A linear negative correlation between yield and PDI was observed during 2013-2015. The lentil yield was found significantly negative correlation $(r=-0.99)$ with the percent disease index of stemphylium blight in technology verification experiment conducted at farmers field of 5 districts. The equation $\mathrm{Y}=-21.44 \mathrm{X}+1870$ and $\mathrm{R}^{2}=0.99$ gave the best fit (Figure 1).

The estimated regression line indicated that the unit rise in the PDI of stemphylium blight disease in farmers field of 5 districts followed recommended and their own cultivation practice during two years of experimentation (within 1-9 scale), there existed possibilities of yield reduction by $21.44 \mathrm{~kg} / \mathrm{ha}$. 
Journal of Agriculture and Natural Resources (2018) 1(1): 51-61

ISSN: 2661-6270 (Print), ISSN: 2661-6289 (Online)

Table 7: Interaction effect between cropping year, location and practice on disease severity and lentil yield in on-farm technology verification experiment during 2013-2015.

\begin{tabular}{lcc}
\hline Year $\times$ Location $\times$ Practice & Stemphylium blight (PDI) & Yield (kg/ha) \\
\hline Y1L1P1 & $43.45^{\dagger}$ & 942.50 \\
Y1L1P2 & 66.47 & 426.25 \\
Y1L2P1 & 43.25 & 998.75 \\
Y1L2P2 & 70.47 & 355.75 \\
Y1L3P1 & 35.70 & 1068.75 \\
Y1L3P2 & 70.85 & 335.00 \\
Y1L4P1 & 35.87 & 1061.75 \\
Y1L4P2 & 65.85 & 499.75 \\
Y1L5P1 & 43.25 & 951.25 \\
Y1L5P2 & 73.57 & 260.00 \\
Y2L1P1 & 44.40 & 932.25 \\
Y2L1P2 & 67.07 & 410.25 \\
Y2L2P1 & 35.52 & 1135.00 \\
Y2L2P2 & 66.12 & 488.00 \\
Y2L3P1 & 36.57 & 1055.00 \\
Y2L3P2 & 67.97 & 408.00 \\
Y2L4P1 & 38.40 & 1035.00 \\
Y2L4P2 & 70.40 & 360.25 \\
Y2L5P1 & 34.95 & 1142.50 \\
Y2L5P2 & 70.12 & 385.00 \\
\hline F Test & 1.17 & 0.96 \\
CV\% & 5.78 & 10.78 \\
\hline † Means of 4 replication. PDI-percent disease index, Kg/ha- Kilogram per hectare. Y1- 2013/14, Y2- 2014/15, L1- \\
Chitwan, L2- Rautahat, L3-Dang, L4- Parsa, L5- Banke. Improved practice (P1) includes improved variety \\
(Black lentil) + seed priming + Recommended seed rate (30 kg/ha) + fertilizer doze (20:40:20 NPK Kg/ha \\
+1 kg/ha B basal doze) + mancozeb 2.5 g/l of water (3 sprays at 10 days interval during vegetative stage) \\
with till while farmer practice (P2) includes only high seed rate (60kg/ha) in relay condition. NS- not \\
significant &
\end{tabular}


Journal of Agriculture and Natural Resources (2018) 1(1): 51-61

ISSN: 2661-6270 (Print), ISSN: 2661-6289 (Online)

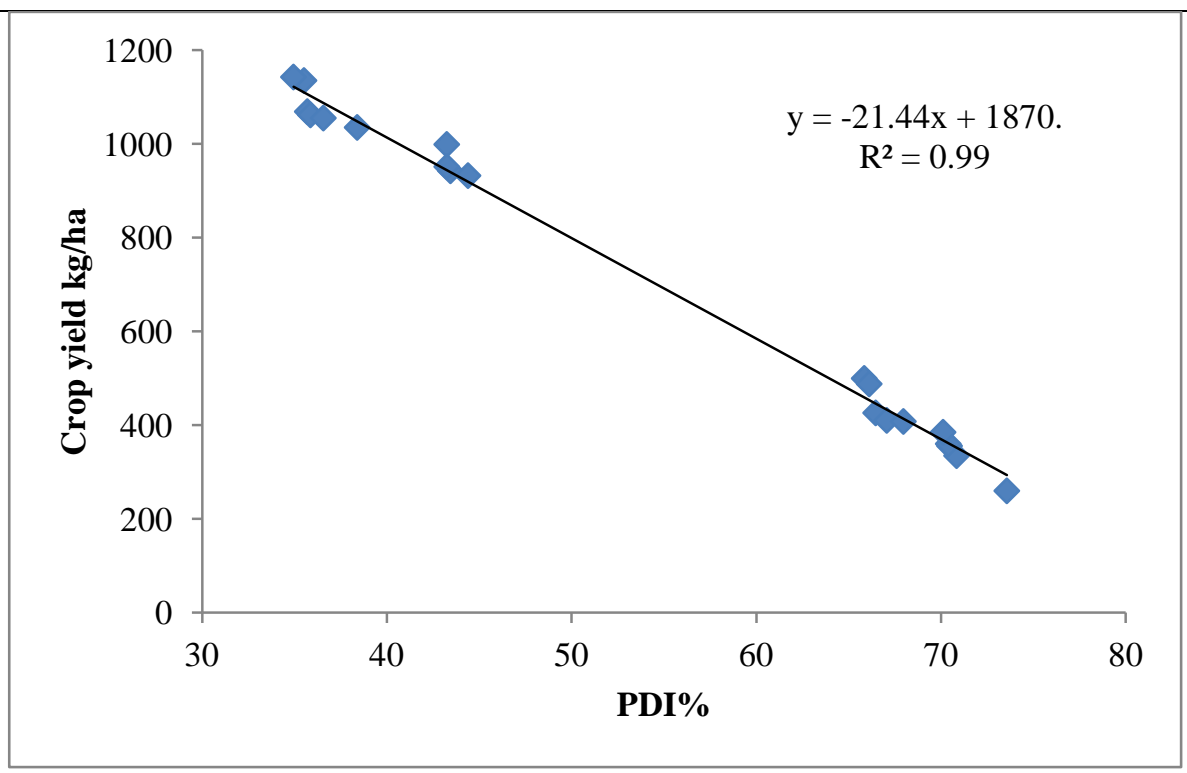

Figure 1. Relationship between PDI and crop yield in on-farm technology verification experiment at five lentil growing districts during 2013-2015

\section{Benefit-cost analysis}

The benefit cost analysis of lentil production at farmer's field of Chitwan, Rautahat, Dang, Parsa and Banke districts from on-farm technology verification experiment during 2013-2015 is presented in Table 8.

The cost of cultivation included all variable cost items such as human labour, power tiller, seed, manure, fertilizer, fungicides, insecticides etc. The average cost of cultivation of the farmers who followed improved technologies were NRS 36250 per hectare compared to NRS 18000 per hectare with traditional practices. With the cultivation of improved varieties along with the recommended practices lentil production was reached up to $1032 \mathrm{~kg} / \mathrm{ha}$ compared to $393 \mathrm{~kg} / \mathrm{ha}$ who followed farmers practice of cultivation.

The higher benefit cost ratio of 2.42 was found from the farmers field following recommended practice of cultivation while those farmers who followed their own cultivation practice (with higher seed rate) only had the benefit cost ratio of 0.97 (Table 8) 
Journal of Agriculture and Natural Resources (2018) 1(1): 51-61

ISSN: 2661-6270 (Print), ISSN: 2661-6289 (Online)

Table 8. Benefit-cost analysis of lentil production by farmers (in ha)

\begin{tabular}{|c|c|c|c|c|c|}
\hline Cultivation Practice & Particulars & Unit & Quantity & Rate (NRs) & Total (NRs) \\
\hline \multicolumn{6}{|l|}{ Recommended Practice } \\
\hline \multicolumn{6}{|l|}{ Cost of cultivation } \\
\hline 1 & Foundation seed & $\mathrm{kg} / \mathrm{ha}$ & 30.00 & 130.00 & 3900.00 \\
\hline 2 & Tractor ploughing cost & Min/ha & 300.00 & 20.00 & 6000.00 \\
\hline 3 & Di-ammonium phosphate (DAP) & $\mathrm{kg} / \mathrm{ha}$ & 90.00 & 60.00 & 5400.00 \\
\hline 4 & Potash & $\mathrm{kg} / \mathrm{ha}$ & 30.00 & 40.00 & 1200.00 \\
\hline 5 & Borax & $\mathrm{kg} / \mathrm{ha}$ & 1.00 & 150.00 & 150.00 \\
\hline 3 & Mancozeb (DM-45) 3 spray & $\mathrm{kg} / \mathrm{ha}$ & 4.50 & 800.00 & 3600.00 \\
\hline 4 & Rogor 2 spray & $1 / \mathrm{ha}$ & 1.00 & 1000.0 & 1000.00 \\
\hline 5 & Labor cost & No/ha & 50.00 & 300.00 & 15000.00 \\
\hline & Total & & & & 36250.00 \\
\hline \multicolumn{6}{|l|}{ Production (Yield) } \\
\hline & Yield & $\mathrm{kg} / \mathrm{ha}$ & 1032.0 & 120.00 & 123840.0 \\
\hline & Benefit & & & & 87590.00 \\
\hline & Benefit/cost ratio & & & & 2.42 \\
\hline \multicolumn{6}{|l|}{ Farmer practice } \\
\hline \multicolumn{6}{|l|}{ Cost of cultivation } \\
\hline 1 & Local Seed & $\mathrm{kg} / \mathrm{ha}$ & 60.00 & 100.00 & 60000.00 \\
\hline 2 & Labor cost & No./ha & 40.00 & 300.00 & 120000.0 \\
\hline & Total & & & & 180000.0 \\
\hline \multicolumn{6}{|l|}{ Production (Yield) } \\
\hline & Yield & $\mathrm{kg} / \mathrm{ha}$ & 393.00 & 90.00 & 353700.0 \\
\hline & Benefit & & & & 17370.00 \\
\hline & Benefit/cost ratio & & & & 0.97 \\
\hline
\end{tabular}

\section{DISCUSSION}

Technology demonstration and dissemination were the key factors to success in improving lentil production and productivity in Bangladesh (Afzal et al., 1999). Along with disease resistant varieties, appropriate production technologies, including optimum planting time, seed rate, profitable seeding ratio in inter and mixed cropping, weed control, seed priming, relay cropping, diseases management, etc., have been developed, recommended, and delivered to the farmers through extension services. Sarker et al. (2004) also reported that to popularize the new technologies, the Government of Bangladesh has launched a technology transfer mission called the Lentil, Blackgram and Mungbean Development Pilot Project (LBMDPP) from its own resources in the 1996/97 cropping season. 
Journal of Agriculture and Natural Resources (2018) 1(1): 51-61

ISSN: 2661-6270 (Print), ISSN: 2661-6289 (Online)

Afzal et al. (1999) also reported that with the cultivation of improved varieties and adoption of appropriate production technologies, lentil production in Bangladesh have raised 28,000 ton per year. According to Neupane et al. (2013), poor access to improved seeds, technical knowledge and services among farmers lentil production sector was not developed so much in Nepal. Although Nepal Agricultural Research Council (NARC) has recommended improved varieties along with production technologies of lentil, the adoption at farmers field has been low due to which the average yield was far below than its attainable yield.

\section{CONCLUSION}

From the technology verification study, the higher crop yield $(1142.50 \mathrm{~kg} / \mathrm{ha})$ with lower disease index (34.95\%) were recorded in the farmers field of Sohanpur (Banke) following recommended practice during second year of experimentation while farmers field from same district were recorded higher disease index $(73.57 \%)$ with lower crop yield $(260.00 \mathrm{~kg} / \mathrm{ha})$ following their own practice of cultivation during first year of experimentation

\section{ACKNOWLEDGEMENTS}

The authors are grateful to Grain Legume coordinator for continuous support to carry out the experiments and providing physical facilities to prepare this manuscript. Thanks are extended to ICARDA and OFID for making necessary arrangements and providing funds to conduct experiments.

\section{Author Contributions}

S.S. designed and performed experiments, analysed data and wrote the paper; S. N. helped during conducting the experiments and recording observations.

\section{Conflicts of Interest}

The authors declare that there is no conflict of interest regarding the publication of this paper.

\section{REFERENCES}

Afzal, M. A.; Bakr, M. A.; Rahman, M. L. (1999). Lentil Cultivation in Bangladesh. Lentil Blackgram and Mungbean Development Pilot Project, Pulses Research Station, BARI, Gazipur-1701. 1999. v. 18. p. 64.

Banniza, S.; Parmelee, J. A.; Morrall, R. A. A.; Tullu, A.; Beauchamp, C. J. (2004). First record of powdery mildew on lentil in Canada. Canadian Plant Disease Survey, 84, 102-103,

Bayaa B.; Joshi, S.; Karki, P.B.; Jha, P. (1998). Lentil disease survey report. Kathmandu, Nepal. 
Journal of Agriculture and Natural Resources (2018) 1(1): 51-61

ISSN: 2661-6270 (Print), ISSN: 2661-6289 (Online)

Grain Legumes Research Program (2012). Annual Report 2068/69 (2011/12). NARC, Rampur, Chitwan, Nepal.

Joshi, S. (2006). Review of important grain legume diseases and their management. In: Proceedings of a national workshop on Integrated Pest Management (IPM). Plant Protection Society, Kathmandu, Nepal. 25-26 August 2006. p. 100-116.

Morrall, R.A.A.; Mckenzie, D.L. (1974). A note on the inadvertent introduction to North America of Ascochyta rabiei, a destructive pathogen of chickpea. Plant Disease Report, $58,342-345$

Neupane, R. K.; Sharma, A.; Aryal, D.; Shah, R.; Gupta, S. R.; Maldonado, K. (2013) Technology demonstration and value chain interventions for commercial promotion of lentil in rice fallows in the terai of Nepal. Journal of International Development and Cooperation, 20, (3), 29-43.

Sarker, A.; Erskine, W.; Bakr, M. A.; Rahman, M. M.; Afzal, M. A.; Saxena, M. C. (2004). Lentil Improvement in Bangladesh. A success story of fruitful partnership between the Bangladesh Agricultural Research Institute (BARI) and International Centre for Agricultural Research in Dry Areas (ICARDA). Asia Pacific Association of Agricultural Research in Dry Areas (APPARI), FAO-RAP, Maliwan, Mansion, 39, Phra Atit Road, Bangkok 10200, Thailand. p. 38.

Wheeler, B. E. J. (1969). An introduction to plant diseases. John Wiley and Sons. Ltd. London. UK. 